\title{
CREATING CUSTOMER RELATIONSHIP MANAGEMENT BASED ON ISLAMIC VALUES: A CASE STUDY OF PT. BANK MUAMALAT INDONESIA TBK
}

\author{
Nuralam Inggang Perwangsa \\ Faculty of Administrative Science, University of Brawijaya, Indonesia \\ E-mail: ing.nuralam@ub.ac.id.com
}

\begin{abstract}
This research aims to provide an overview of the implementation of Customer Relationship Management (CRM) based on Islamic values on PT. Bank Muamalat Indonesia TBK as the first sharia bank in Indonesia. It is also reviewed the current status of CRM at BMI and; the challenges and problems facing BMI and developing CRM strategy. Moreover, it explores the nature of CRM in context of business organisation and offers a religious perspective pertaining to organisation and management. The key successful of CRM is founded on trust, commitment, shared goals, and mutual benefits, while people, process, values, and images are the key principles of CRM. According to the key of successful and the key principles of $\mathrm{CRM}$, the organisation can create strategic relationship implementation. Thus structure, staff, style, systems, and schemes are the 5-core elements of strategic CRM. The author will explore on those core elements what will be influenced by Islamic values extensively to make Excellent Customer Service. In fact, BMI has been applying good CRM where Islamic values can be seen on how the employees interact with the customers. The implementation of Islamic values create unique atmosphere of business activities and make it differs than other banks. However, some challenges are faced by BMI in system, cultural, staff, and networks issue. Nevertheless, the recommendations have been taken for this research is presented as the positive feedback of development.
\end{abstract}

\section{KEY WORDS}

Customer relationship management, Islamic values, excellent customer service.

In term of purpose, Islamic banking do the same way with conventional bank but it operates basically on sharia ${ }^{1}$ principles. What its difference that all operations and activities of Islamic banking are derived from sharia law, which guide the crucial distinction in many parts of the conventional. Islamic banking also applies profit sharing much stable rather than the interest based system (Siddiqi, 2002; and Zarqa, 2003) resulting in prevention of fluctuations in rates of return the impossibility of refinancing through debt (Yusri, 2005).

It becomes obvious that many business organisations were placing an enormous focus on customer relationship management (CRM) to achieve customer satisfaction. CRM is described as a management which consists of identify, maintain, and enhance relationship between company and customers. It is also people argued that customer relationship management (CRM) without trust, commitment, shared goals and mutual benefits will be not successful (Cravens and Piercy, 2006; Egan, 2007); and more likely similar with social exchange theory where trust and equity are the key points of this theory (Donaldson and O'Toole, 2002).

Islamic Values. Sharia principles (Islamic values) in work-life provide an atmosphere of work which those values are not apart from business. Islamic values determine individual choices, not only maximising profit, but also maximising social welfare, which are set out in the Qur'an ${ }^{2}$ and Hadith ${ }^{3}$ (Ebady, 2004: Islamic Relief, 2008). Deeply, Islam is not only a belief but also a way of life, because it goes beyond worship to embrace many aspects (Ali, 2008). Thus, as a Muslim, Islamic values should be reflected on behaviour of each person

\footnotetext{
${ }^{1}$ Sharia means «the way to the source of life» and now is used to consign to legal system in keeping with the code of behaviour called for by the Holly Qur'an (Koran).

${ }^{2}$ The Quran is the central religious text of Islam, which Muslims consider the verbatim word of God.

${ }^{3}$ Hadith is used to denote a saying, act or tacit approval, validly or invalidly, ascribed to the Islamic prophet Muhammad.
} 
who embraces Islam in every aspect of their life; in other words, we have to internalise Islamic values.

In Indonesia, Bank Indonesia as the central bank has formulated a grand strategy of Islamic banking market development as a comprehensive strategy of market development. The strategy covers aspects, such as: creating inclusive and universal image of Islamic banking, mapping a more accurate market segment, developing more various products, and improving services quality (www.bi.go.id, 2011). The strategy as a form of supports from central bank to Islamic banking in Indonesia and will be a guidance of market development. Islamic banking day by day has been competing hardly with conventional bank; it needs strategy to win the share market. This is because in term of business volume, Islamic institutions cannot compare vis-à-vis with conventional one. This is because many customers do not understand and do not receive enough information about principles which are run by Islamic institutions.

The company has selected for this research is PT. Bank Muamalat Indonesia Tbk. (BMI). Established in $1^{\text {st }}$ of November 1991, PT. Bank Muamalat Indonesia Tbk (BMI) is the first commercial bank in Indonesia which has been implementing sharia principles in their operation. BMI, which is endorsed by Majelis Ulama Indonesia (MUI - Indonesian Islamic Scholars) and Indonesian Government, started to commercial operations in $1^{\text {st }}$ of May 1992 (www.muamalatbank.com, 2011). The initiative of establishment thought on MUI seminar entitled «Problems of Bank Interest» in August 1990.

Majelis Ulama Indonesia (MUI - Indonesian Islamic Scholars) as a board in BMI has a function in supervising all transactions are according to sharia principles. Those scholars are qualified advisors who consist of top Muslim scholars who are well versed in Islamic law that relates to transactions and business dealings. Certainly, the board has to be independent and screens investment strategies, implementation, monitoring and reporting (Zaher and Hassan, 2001).

The Form of Customer Service at PT. Bank Muamalat Indonesia Tbk. The author assess whether BMI applies Islamic values carefully in customer relationship management (CRM) to create excellent customer service and whether the factor why they implement Islamic values in their customer relationship management (CRM). The research also takes into consideration aspects of customer relationship management, Islamic values, and excellent service. In addition, it will be explain the successful implementation of customer relationship management which consists of aspects such as Structure, Staff, System, Style, and Scheme.

In Islamic principles, it is apparently said that internalisation of Islamic values is crucial to create mindset and thought of doing service as the basic foundation. It is an obligation of BMI to perform Islamic values in their business activities to every customer. Moreover, excellent service has several factors such as preventative analysis, field organisation support, people and process, consumer system support, telecommunication support. Among those factors, people and process is the most crucial factors to drive customer service effectively, meanwhile other factors are the supporting factors to support people in delivering service to the customers.

Brink and Berndt (2008) argues that good customer service is created by a process, not instantly made. It includes of trial and error when a company do communication with customers and receive their feed back as an input to fix, modify, and create strategic service. Some studies said that the successful of CRM is primarily based on few factors such as Trust \& Commitment; and Shared Goals \& Mutual Benefits, as the key principles. Meanwhile, another study claims that technology is the basic principles of CRM (Cravens, Piercy, 2006).

Since many studies prove that Trust \& Commitment, and Shared Goals \& Mutual Benefits are the important factors in successful of CRM, the author believes those factors is highly positive with Islamic values or even more effective when it is adopted in CRM. In this research, the author tries to place Islamic values as the foundation of creating different «taste» of Trust \& Commitment, and Shared Goals \& Mutual Benefits. The study shows that when we manage Human Resource as our strategic value, it will create excellent customer service. In addition, the author needs to look the impact effect of Islamic values when it is implemented on BMI. According to the arguments, it is important to know that Islamic 
banking able to compete with conventional bank or even create certain standard and specialty that will win the market.

\section{LITERATURE REVIEW}

Every company needs to clarify business guideline as business mission (Gronroos, 2007) to determine in which markets the company should operate and what kind of challenge should be tackled. In addition, the guideline is manifested in service concept (ibid) to express the idea to solve certain customer's problem in definite approach. Besides, the company has to formulate from their resource even from external perspective (Porter, 2004) or internal perspective (Barney, 2006) to create strategic service concept as one of their competitive advantage.

Zeithaml and Grembler (2009) explain services are forms of actions, processes, and performances offered or coproduced by one organisation or person for another organisation or person. In other words, customer service is all activities and process of the organisation has to add value to their products and service, while Turban et al. (2002) identifies customer service as a series of process designed to get customer satisfaction.

Customer Relationship Management as the Form of Customer Service. CRM concentrates on proceeding customer relationship, developing customer loyalty, increasing profitability (Brink and Berndt, 2008) as our main business goal. In addition, Cravens and Piercy (2006) claim CRM is created by maximising information technology in a company. The success of relationship management consists of few key factors as followed:

Therefore, the customer relationship management (CRM) without trust, commitment, shared goals and mutual benefits will be not successful (Egan, 2007). This is the reason why the company fails to make customer loyalty when they ignoring those aspects. CRM is a holistic approach and not talking about technology which focus on customer's satisfaction rather than structure of organisation. It is like an internal competency a company has (Barney, 2006) instead of a list of technologies (Prahalad and Hamel, 1990) that will win customer loyalty. However, technology is not a separate part of CRM, yet it is as a support aspect to make excellent service of our company (Doole and Lowe, 2008).

Strategic Relationship Implementation. A relationship management strategy will eventually be implemented in specific of a company's functional area, for example, in marketing or human resource management (HRM) practices. Those practices will make a system and synergise onward when our company make a relationship with its partner. Donaldson and O'Toole (2002) introduce 5-S framework what extent to help plan for relationship implementation, which are Structure, Staff, System, Style, and Scheme. The purpose of the 5-S framework is connecting corporate strategy to the implementation of social and structural attach in relationship. Each of these instruments has a role in daily operational CRM strategies.

The characteristic of Islamic banking operation is based on partnership and mutual benefits principle provides an alternative banking system with mutual benefits both for the public and the bank (Tijjani, 2011). This system will give priorities to aspects related to fairness in transaction and ethical investment by underlining the values of togetherness and partnership in production, and by avoiding any speculative activity in financial transaction (Bank Info, 2011). With Islamic banking, all partners involved in financial transactions share the risk and profit or loss of a business, and no one takes a predetermined return. This correlation is the essential difference between Islamic and conventional banking which has its main goal in optimising shareholders wealth (Dar and Presley, 2000). By providing various products and banking services supported by various financial schemes. Islamic banking will be a credible alternative that can be benefiting for all without exception.

Islamic Values in Customer Relationship Management (CRM). Strategic Human Resources Management (SHRM) is defined as framework human resource management practices to attain business outcomes (Schuler and Jackson, 2007). Furthermore, strategic HRM centres on how an organisation maximising their objectives to their employees. Due to people is a key source of competitive advantage, and those who implement the strategic 
plan, top management must take it is condition into their account in developing corporate strategies (Amstrong and Baron, 2007).

Sharia principles (Islamic values) in work-life provide an environment of work which those values are not apart from business. Islamic values determine individual choices, not only maximising profit, but also maximising social welfare (Ebady, 2004: Islamic Relief, 2008). Consequently, as Muslim, Islamic values should be reflected on behaviour of each person who embraces Islam in every aspect of their life; in other words, we have to internalise Islamic values. The process of internalisation involves ethical knowledge in business practices; awareness of those Islamic values which are to be transferred and internalised; expertise in the internationalisation of values, and knowledge of relevant laws (Rizk, 2008). Those who are showing Islamic values reflected in a good work

The internalisation of Islamic values in practices strengthens certain qualities, such as honesty, trust, loyalty, and flexibility. In addition, when BMI and its employees have internalised the Islamic values, it strengthened cooperation among them and their achievements were immense at the time (Rahman, 1996).

Islamic values can guide the managers and executives in every business organisation in the right path. It increases the reputation of the business organisation, certifies its constant development and helps to get customer satisfaction. The possible contents of Islamic values are wide and vary. Some of them might be universally accepted and some might not be universally recognised as Islamic values. However, all of them can positively impact the progress of business organisation. The key values of management system in Islamic perspective are extracted from the Quran (words of God) and the Hadith (words of Prophet Muhammad). Brainnes and Pollard (2010) determines 10 Islamic values as Intention (Nya); Always mindful of the God (Taqwa); Kind-heartedness and care while feeling the presence of God (Ehsan); Justice (Adl); Trust (Amana); Truthfulness (Sedq); Conscientious of selfimprovement (Etqan); Sincerity and keeping promise (Ekhlas); Consultation (Shura); and Patience (Sabar). Various values of HRM in Islamic perspective give as description of strategic concept what aims to achieve sustained competitive advantage by assuring the organisation maximising their value to employees.

Excellent Customer Service (CS). Excellent customer service mainly describes as an integral part of CRM (Brink and Berndt, 2008) and interpretation of strategic process of how service process itself delivers to their customers. Excellent CS can be realised by training and development of our employees (ibid). The key elements of effective customer service model introduced by Nicholson et al. (1996) depict integrated five elements which interrelated each other. The model can be explained as following:

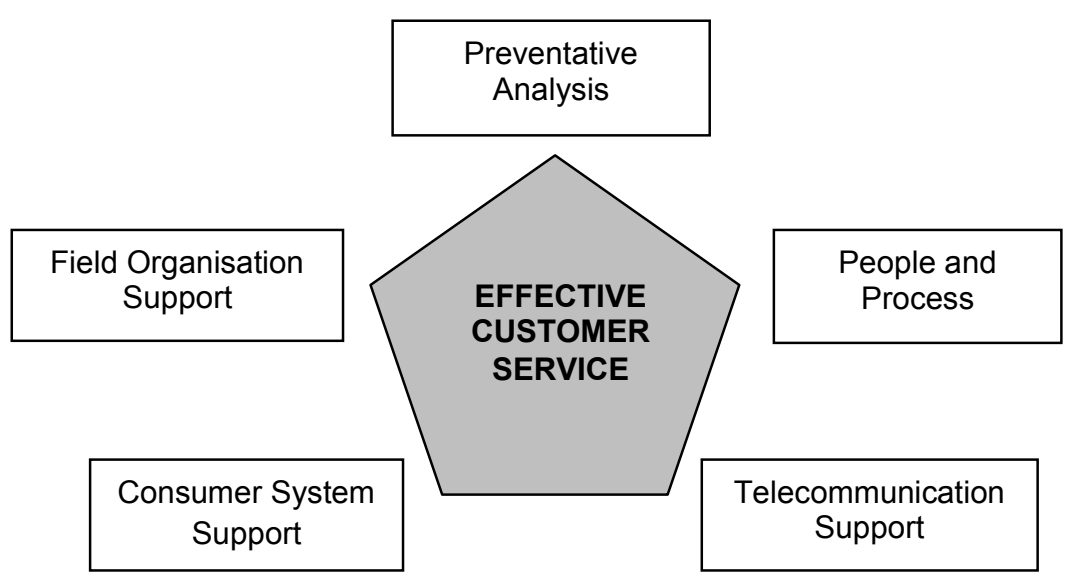

Figure 1 - The Customer Service Pentagon Source: Nicholson et al., 1996.

Nicholson (ibid) claims that People and process is the most crucial factors to drive customer service effectively, meanwhile other factors are the supporting factors to support people in delivering service to the customers. One of the obstacles at this point is how to 
train and assimilate the right training to them. Nevertheless, it is important to company to assure amongst their policies, procedures, support, and employees to be customer oriented and operate them efficiently.

Although, people-and-process is the important element, other elements of creating effective customer service such as Telecommunication support, Consumer system support, Field Organisation Support, Preventative Analysis are not a separate part of CRM, yet they are as a support to make excellent service of our company (Nicholson, 1996). CRM can flourish if our company well planned to make co-ordinate direction with all resources (Egan, 2007).

The practical study of CRM and customer relationship has grown intensively. The phenomena have attracted both the business practitioners and the academicians. CRM arises when business organisation considers customers as partner and always set great endeavour to make psychological and emotional state and something to do with customer attitudes.

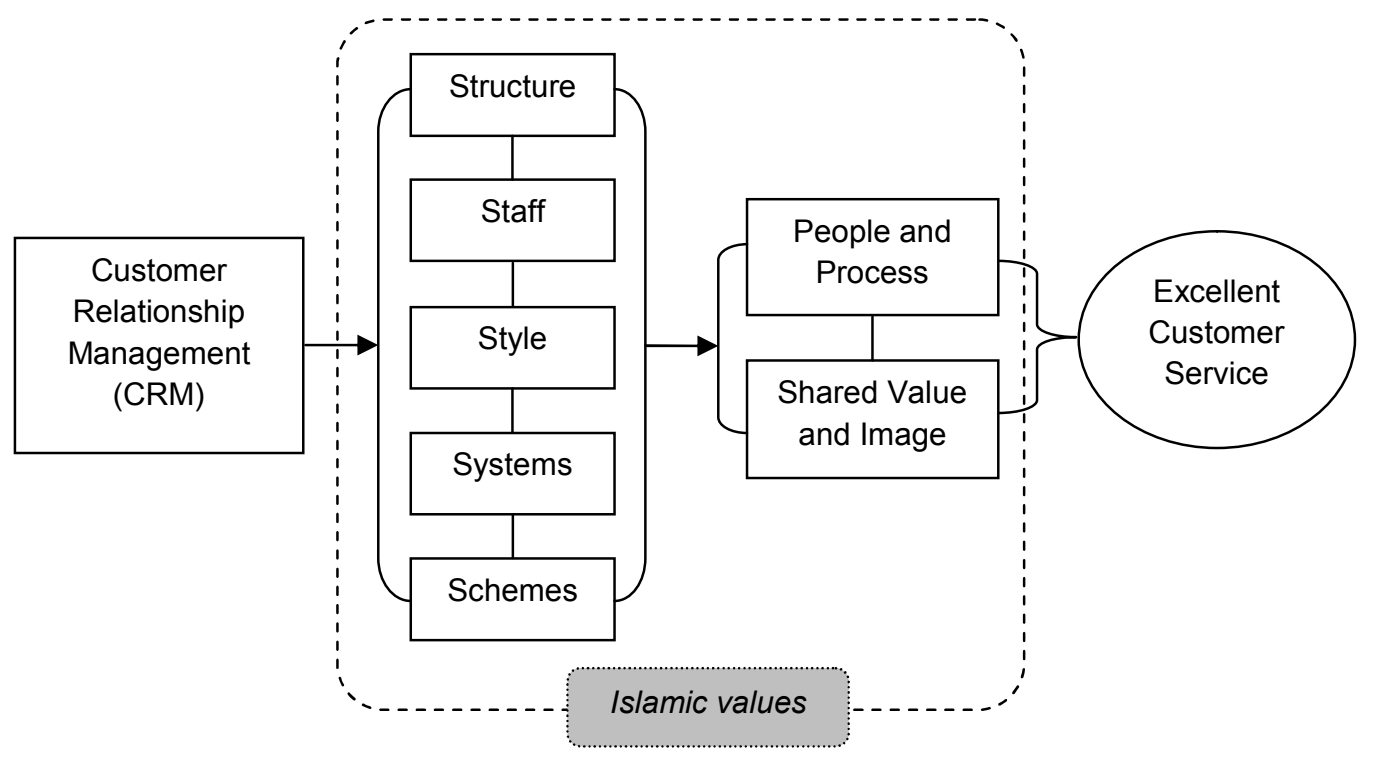

Figure 2 - Research Framework

Source: Adopted by the Author, 2016

The picture depicts the process of CRM creating excellent CS. The CRM involves with 5-core elements (structure, staff, style, systems, and schemes). These core elements are integrated as a formula in CRM implementation. Moreover, CRM is basically founded by 2 successful factors, people and process; and shared value and image. If we manage those factors in our CRM implementation, it will boost the creation of good performance and excellent CS. At the same time, 5-core elements and 2 successful factors of CRM are framed into Islamic values. The author claims that Islamic values will make CRM implementation differs than conventional or prior study about CRM. In addition, religious values can give profundity and restraint to spirituality and thus make it more appropriate, stable, and secure. However, there are some difficulties with making religion the standard for judging the correctness of spirituality within business.

Several studies regarding the relationship between CRM and Islamic Values have been done. Ali and Al-Owaihan (2008) exposed the relationship of CRM with customer satisfaction has a significant impact on business; which work ethics or values will enhance the significant intensity on the relationship, customer satisfaction, and boost the level of customer happiness. Cavanagh and Bandsuch (2002) as business leaders, whose contributing positively to their careers with spiritual concept, assumes that spirituality can increase reliability, integrity, and enables a person to develop good morals (virtue) at the workplace. Pramanik (2002) justifies the successful performance of new economic policy founded on Islamic values, justice and fairness, which enabled the country to achieve quick growth with full employment. Ali (2008) provides an-depth review of Islamic Work Ethic (IWE) that 
declare particular factors, especially faith, have developed and eased the emergence of work ethic. Cerimagic (2010) proves that sharia principles induce companies to be wary of factors, such as interest, uncertainty, or risk. The law is created to protect the welfare of all the parties involved. As a result, the law seeks to present justice and fairness to both companies and customers. Hashim (2010) aims to observe HRM from the Islamic perspectives and its implications on organizational commitment amongst selected employees in Islamic organizations in Malaysia. The results show that the Islamic approach in HRM was positively and significantly correlated to organizational commitment. Around $45 \%$ organisational commitment variance clarified by the Islamic approach in HRM. Jalil et al. (2010) revealed that ethics and ethical behaviour are two features which are increasingly being focused on the business climate recently. Shamsudin et al. (2010) studied the impacts of the Islamic work ethic on the correlations between relationship marketing and customer satisfaction. The study concludes that Islamic work ethic will enhance a positive and significant relationship between relationship marketing and customer satisfaction. In term of basis of this study, the author realises that evidence for a positive contribution by religious commitment particularly Islamic values is extremely limited. However, the author tries hardly to find sources as many as he can to support arguments on his research.

Failure of CRM. A study taken by Accenture (2002) found failures in CRM as followed: 1) Whilst top managements overwhelm with technology to strengthen their CRM, majority say that personal support from management is decreasing. 2) Failure in CRM plans is the evidence of disconnection between organisation strategy, vision, value, and execution. 3) Too many projects in CRM can make a confusion and loss of employee creativity.

Moreover, CRM as a new marketing concept is criticised by Gummesson (2000) who illustrates CRM is an old model with new clothes, possibly the "emperor's new clothes». By extent, Ganeshram and Myron (2002) argue that CRM is not a neo-concept because it was practiced for centuries and just cosmetics of a marketing model.

In term of the case study (BMI) CRM which is derived from Islamic values can be fail if BMI cannot determine their form of CRM. Since strategy, vision, value, and operation of BMI is on sharia principles, their CRM have to in line with those principles.

\section{RESEARCH METHODOLOGY}

Since the author use social constructionism approach to search human phenomena in particular object (Jankowicz, 2005; Easterby-Smith et al., 2008; Saunders, 2009) the author designs his research into qualitative research. This justification is derived from the proves of earlier researchers that qualitative research has a direct link to social constructionism rather than positivism (Easterby-Smith et al., 2008). It is called qualitative research because it is emphasising to gather an in-depth understanding of human behaviour with focusing on smaller samples of research object (Denzin and Lincoln, 2005). Jankowicz (2005) clearly argues that qualitative research find out the nature, content, and meaning of what the sample said instead of the number who are saying it. The main methods of this research are depth interview with personal discussion. Due to qualitative research relatively small scale, it generally can be completed quickly and less costly than quantitative surveys and it is as the advantage of qualitative research.

The author has a verdict to use case study because the author questioning «how» and "why» questions to be answered and has lack of control over the events of recent phenomena in real-life (Yin, 2009). Moreover, Yin (ibid) describes case study as a method to look carefully practical and real-life occurrence of the actual interactions between variables or events. Yin (ibid) suggests that case study is particularly appropriate to use in research question which needs detailed understanding of a process such as in society or organisational. In this research, the author will look up into the way of Islamic values in CRM can create excellent CS of BMI.

Sampling techniques provide a wide of methods that enable the researcher to decrease the amount of data they need to collect and analyse. In this study my sample are coming from BMl's management (two persons: Service Division Head and Service Division Officer of BMI) and BMl's customer (five persons). 


\section{FINDINGS AND DISCUSSION}

The thought of respondents on customer relationship management (CRM) according to Islamic values on Bank Muamalat Indonesia (BMI) diverse each other. The author divides two sections of interview, the top management and the customers. Firstly, the author interviewed from BMI perspective of 2 (two) persons in management as my sources. In this section, the questions relate to form of basic foundation of business, customer relationship management (CRM), Islamic values, and the evaluation of application amongst those aspects on BMI. Secondly, the author interviewed from the customer perspective and took 5 (five) customers with selected criteria. In this part, the questions to answer link to the evaluation of what BMI has done on their business, CRM, Islamic values, and excellent service.

BMI Perspective. Many proved arguments that BMl's vision and mission of business specify the form of business and the strategy adopted. The impact of business foundation of $\mathrm{BMI}$ on CRM is so immense. BMI commits to be the first Islamic banking which considers not only national but also international insight. BMI always serves their customers in fast, precise, and full responsible. For instance, when there is something error with computer system and disturbing transactions, BMI uses humanity approach and gives promise to their customer on fixing the problems quickly. Also, BMI admits commitment to customers as standard of achieving customers' satisfaction and loyalty. The respondent also adds that shared goals and mutual benefits in BMl should interpret into clear understanding in order to make the customers know about the difference between Islamic banking and conventional system or even BMI with other Islamic banks.

The successful of BMI applying customer relationship management (CRM) that staff is the main successful factor of it. The processes from recruitment, selection, and to hire employee based of basic understanding on Islam, aim to accelerate the Islamic banking understanding and willingness to think and work anchored in Islamic values. Regarding Islamic Values on CRM at BMI, there are 3 (three) critical points; management commitment, supporting policy to service quality, and awareness of employees and customers; as the key successful of application. The central mindset of CRM on BMI is that company with customers, hand in hand creating reciprocal and open relationship.

Greenberg (2010) assumes people and process are the key principle in applying CRM. The key performance indicator of staffs such as morals, responsibility, teamwork, and discipline is needed to meet several targets properly. Sharia principles on BMI indirectly become working culture on BMI. Every employee has to adopt and use those principles in work-life.

The Way BMI manages Its Organisation and Strategy. BMI upholds the practice of honestly since the onset of recruitment. In addition, the Bank prohibits receiving gifts in any forms from customers and business partners. BMI is also strict in addressing reputation risk caused by employee's behaviour which is not accordance with culture, ethic and law.

The performance evaluation of the employees is based on scoreboard, based on financial and compliance aspects. The appointments of staff and officials must go through oral and written oath procession on the 7 (seven) behaviours as the code of conduct that the employees must be accounted for and promise to 1) Obey the regulations and provisions of the Company; 2) Keep the Bank's and the Company's confidentiality; 3) Refuse to accept any compensations in any forms in relation to tasks or position; 4) Uphold the Company's and employees' honor; 5) Work according to the Sharia principles; 6) Be reliant upon Islamic morals in conducting daily routines; and 7) Responsible for their mistakes and violations. BMI always upholds beneficence oriental business ethics, especially in relation to customer's and stakeholders' satisfaction.

Structure (Networks and Services). In operating its business activities, BMI, with its headquarter in Jakarta, at present has 75 offices, 92 sub-branch offices, 158 cash offices, 43 Muamalat outlets, and 4.103 Online Post Outlets (SOPP). BMI is able to provide a variety of complete and convenient services as any modern bank. The three main aspects of services, which are Premises, People and Process are the major concern of BMI in its bid to improve services. 
Staff (Human Resource). Human Resources (HR) is the key factor implementing business strategy. In 2010, BMl collaborated with several consultants to build integrated and phased HR system. The development is referring to the organization's needs in order to prepare human capital-oriented quality and quantity. In December 2010, the first step of the new policy was taken by reforming the employees' job grading. Meanwhile, the new remuneration scheme and other policies will be gradually implemented in 2011. BMI implements a special technique to train their human resources to be more competent, skilled, discipline, attentive, creative, idealist, hardworking, strong and loyal toward common goals. The division recruits, administers and develops employees to be more productive individuals, well mannered and professional in terms of achieving the vision and mission of BMI

System (Information Technology). The BMI already conducted a review and improvement of policy and procedures on the Company's information technology followed by Quality Assurance process to ensure that there were no missteps in following the written procedures. Besides, the BMI started the development of Data Centre and reallocation of Disaster Recovery Site, which meets the criteria required by the industry and the Company, also standardized the use of desktops by implementing Seat Management model, effective in 2010. The technology Division realized that the wide distribution of offices and the big number of desktops are not fully supported by the limited number of employees. This is why the division came to the conclusion that Seat Management model was the best choice

Customer Perspective. Customers replied trust in business and the competition process can be achieved with maintaining long term relationship with customers or clients. In another meaning, banking business where the customers who want doing transaction determined by how trust of both parties. Particularly, in sharia banking (Islamic banking), people sure and believe that Islamic banking operates based on sharia principles where it becomes the consideration of the customers to deposit their money on it. The trust should be promoted slowly and continuously, because trust cannot build instantly. If the company believe this thought increase customer trust, thus those long term relationship can be tied automatically. In order words, the trust in company can be said as the positive implication of reliability of employees in the company.

Additionally, the commitment is one of the factors in business ethics. The commitment on interaction between company and its customers becomes the main concern of company and it could be the added value as well. In term of BMI, the commitment is seen as providing products and services with proper quality, handle problems wisely, and give right suggestions to the customers. Therefore, conscious or not, shared goals and mutual benefits are the product of the commitment amongst company, employees and customers.

Islamic Values on CRM of BMI. So far, the concept of customer relationship management (CRM) on BMl has been successful and satisfying the respondent where shared goals and commitment as the prominent factors in term of profit sharing of business; while another respondent said it has been successful but have not satisfying yet. However, the concept of CRM on BMI is not much different than that of conventional bank. Personally, a respondent argues BMI able to manage the customers until the problems they have solved properly, while in other banks the customers frequently cannot well handled. Yet it is claimed that BMI should upgrade their CRM, for example deft employees, due to compete with other banks which are established for years.

A respondent sees that work climate on BMI is quite good. The most interesting is on praying time. BMl always breaks all the transactions when the time for praying is coming. BMI provides time for their employees and customers to pray in time. Moreover, BMI also grants enough space inside the bank as prayer room and calling all persons who want to pray in congregation.

What is more, Islamic values in BMI is well performed through the services given, where the employees dress modestly with showing Islamic dress like Islamic cap for males and Hijab for females. The employees of BMl frequently greet the customers with Muslim Greetings (Salam) when they meet each other and stand up when the customer approaching customer service desk. Those conditions make BMl distinct with any other conventional banks and Islamic banks as well. 
What is impressing is that BMI is not giving grandiose promises to the customers. For example, $\mathrm{BMI}$ is more profitable on investment and security rather that other banks. In fact, BMI just promises the money we deposit on BMl is secure and will be used in sharia investment instead of giving promises which hardly to achieve. Moreover, the customers can give critics and suggestion if they found mistakes in services or transactions, which be served wholeheartedly by employees.

The respondent thinks that the internalisation of Islamic values is started from Staff. If this factor already settle, others factors will follow it. Thus, when staff applies Islamic values is not based on coercion and do it as their willingness, as a result BMI can avoid moral hazard which comes from human factor. In addition, another respondent said structure of BMI such as corporate culture has major influence. Consequently, all the employees have to do all activities involving CRM based on what it is said / written on corporate culture.

The Challenges and problems faced by BMI and developing CRM strategy. However, one of the obstacles implementation of Islamic values is on cultural issue. Islamic banking in Indonesia was firstly introduced in 1992 after so many years Indonesia has conventional banking system. Consequently, the thought of Indonesian is based on conventional and need to enlighten comprehensively when we want to adopt Islamic values in our institution. So far, the condition of application is acceptable, but need to well inform.

Meanwhile, the critical aspect about CRM of BMI is on system (information technology). BMI itself is too late to start realising that system (information technology) is one of the imperative factors in CRM. Moreover, BMI barely provides system which partial service banking. Its online and mobile banking merely for checking balance, transfer, and checking last transactions, whilst others can do more complex.

Another fact that CRM on BMI is not a particular issue ought to learn frequently. Meaning, BMI realises that Islamic values is the only factor has to learn continuously. It is because Islamic values is so enormous and various in thoughts. If BMI learns Islamic values deeply, intensively, and sincerely, there are thoughts of empowerment of small business, CRM, and customer satisfaction. Islamic values and CRM are like in a layered circle where Islamic values are at the outer layer, while CRM and other thoughts are in the core layer.

\section{CONCLUSION AND RECOMMENDATIONS}

The current status of CRM at BMI surely links to the basic business value of BMI. CRM is one of many strategic ways try to implemented by BMI in order to achieve business main goals. The characteristics of customers are widely various, meanwhile those who are fanatic with sharia principles, prefer to use BMI as their partner business.

The two key successful of CRM, trust and commitment; shared goals and mutual benefits, have fruitfully meet with basic business values of BMI. Obviously, keeping the trust of customers lead BMI to commit to be first Islamic banking which considers not only national but also international thought. Corporate culture of BMI is influenced by its human factor, the supremacy of its proposed products or service, network, and superior technology to success of the business. In term of human factor, BMI concerns on CRM that can be proved through the processes of hiring employees and the strategic of training which already started in 2010.

Generally, the implementation of CRM on BMI is quite successful where most of the customers have been satisfied. The concept of CRM on BMI is commonly same with that of conventional bank. What make it distinguishes between CRM on BMI and other banks is the value added of service itself. BMI succeed covering CRM with Islamic values. They want to promote, campaign, and inform broadly that all the business activities on BMI are based on sharia principles. How to dress modestly; how to greet; and how to serve are the evidences of what the customers feel about Islamic values on BMI.

System (technology) is one of 5-core-values on BMl also has important role. The development of system, in term of internet service in Islamic bank, in BMI particularly, is still weak than that of in conventional bank. Cultural issue become the challenge of $\mathrm{BMI}$ in developing CRM based on Islamic values. We cannot refute that Islamic banking system is a quite new system over the world. The information about it is also inadequate to understand; the differences amongst others still the major issue to tackle. 
It could be recommended that staff training is still the best approach to upgrade skills capacity of employees. Excellent service of company mostly comes from employees' trainings and upgrading. If the BMI can realise strategic planning to improve its employees' skills and capability, the problems where are complained can be cut down. Feedbacks from customers said that factors about Product Knowledge, Speed \& Accuracy, and Thoroughness are needed to be focused on. In order to raise its score of internal assessment regarding customer satisfaction, BMI may hold service training periodically and directly after that assessment/evaluation.

It is also suggested that BMI needs to utilise every opportunity and maximise their promotion and campaign to broaden out the information about sharia principles and Islamic banking. The reason is that through campaign and promotion of Islamic banking, more customers will attract to use that institution.

It is essential for BMI to develop system (information technology) factor which already drop behind from conventional bank. Revamping infrastructure in system (information technology) is one BMI should be done immediately. Recently, company which develops CRM basically is prioritising IT as their key factor of service support. In term of this factor, it is necessary for BMI to create sustain customer database which can help knowing the customers. Information technology that BMI has is awfully limited compared to other banks. Although, BMI had been develop a call centre named "SalamMuamalat», but it is not accompanied with well e-banking (internet banking) and well mobile banking where other sharia banks had been well developed.

Indeed, the author does not skip structure and scheme of BMI as another critical factor. Structure in this aspect could be management supports, such as motivation and planned strategy acceleration, are needed to drive CRM policies in realising excellent service. With those supports, it surely will speed up and strengthen CRM strategy. The changing of management surely affects CRM strategy. The authors suggest BMI to make master plan of CRM what as a main goal to achieve no matter the managements changed.

\section{REFERENCES}

1. Accenture (2002). Computing SA, 22 (26) 15 July, p.13.

2. Ali, A. J., and Al-Owaihan, A. (2008) «Islamic work ethic: a critical review». Cross Cultural Management: An International Journal. Vol. 15 No. 1, pp. 5-19.

3. Amstrong, M. \& Baron, A. (2007) Handbook of Strategic HRM. London: Jaico P. House.

4. Barney, J.B. (2006). Strategic management and competitive advantage: concepts and cases. London: Prentice Hall.

5. Brainnes, M. \& Pollard, D. (2010) «Human resource management with Islamic management Principles». Personnel Review. Vol. 39 No. 6, 2010. pp. 712-727.

6. Brink, A. and Berndt, A. (2008) Customer Relationship Management \& Customer Service. South Africa: JUTA Academic.

7. Cavanagh, G. F. and M. R. Bandsuch: 2002, «Virtue as a Benchmark for Spirituality in Business», Journal of Business Ethics 38, 109-117.

8. Cerimagic, S. (2010) "The effects of Islamic law on business practices». Education, Business and Society: Contemporary Middle Eastern Issues. Vol. 3 No. 1, pp. 40-47.

9. Cravens, D. W., and Piercy, N. F. (2006) Strategic Marketing ( $8^{\text {th }}$ Edn.). New York: Mc Graw Hill.

10. Dar. H. (2000).The Lack of profit loss sharing in Islamic banking: Management and control imbalances, International Journal of Islamic Financial Services. 2(2).

11. Denzin, N., K. \& Lincoln, Y., S. (2005). The Sage Handbook of Qualitative Research (3 ${ }^{\text {rd }}$ edn.). California: Sage.

12. Donaldson, B. and O'Toole, T. (2002). Strategic Market Relationships: From Strategy to Implementation. London: John Wiley \& Sons, Ltd.

13. Doole, I., and Lowe, R. (2008) International Marketing Strategy: Analysis, development and implementation ( $5^{\text {th }} E d n$.). London: Cengage Learning EMEA.

14. Easterby-Smith, M., Thorpe, R., and Jackson, P. R. (2008) Management Research (3 ${ }^{\text {rd }}$ Edn.). California: SAGE Publications Ltd. 
15. Ebady, Atiq (2004). http://www.darulislam.info/Article60.html. Access on $27^{\text {th }}$ of July 2015

16. Egan, J. (2007). Marketing Communication. London: Thomson Learning.

17. Ganeshram, R., and Myron, D. (2002) The Truth About CRM Success \& Failure. http://www.destinationcrm.com/Articles/Editorial/Magazine-Features/The-Truth-AboutCRM-Success-\%26-Failure-45491.aspx. Access on $28^{\text {th }}$ of July 2016

18. Greenberg (2010) Managing behavior in organizations ( $5^{\text {th }}$ Edn.). London: Pearson.

19. Gronroos, C. (2007). Service Management and Marketing: Customer Management in Service Competition ( $3^{\text {rd }}$ edn.). England: John Wiley \& Sons, Ltd.

20. Gummesson, E. (2000) «Relationship marketing - the emperor's new clothes or a paradigm shift?». Marketing and Research Today. February, pp. 53-60.

21. Hashim, J. (2010). «Human resource management practices on organisational commitment. The Islamic perspective». Personnel Review. Vol. 39 No. 6.

22. Islamic Business (2011) http://islamicbusiness.sg/islam-and-business/what-is-thedifference-between-interest-and-profit. Access on $12^{\text {th }}$ of July 2015

23. Jalil, A. D. M., Azam, F., and Rahman, M. K. (2010) «Implementation Mechanism of Ethics in Business Organizations». International Business Research. 4(3); October.

24. Jankowicz, A.D (2005) Business Research Projects ( $4^{\text {th }}$ edn.). Luton: Thomson Learning.

25. Nicholson, J., Kemp, J., and Linnell, P. (1996). "Does the rhetoric of customer service match the reality?». Managing Service Quality. Vol.6 (3), p.7.

26. Porter, M., E. (2004). Competitive Advantage: Creating and Sustaining Superior Performance. New York: Free Press.

27. Prahalad, C.K., and Hamel, G. (1990) The Core Competence of the Corporation. Harvard Business Review. May/June, p. 71-91.

28. Pramanik, A.H. (2002) «Islam and Development Revitised with Evidences from Malaysia». Islamic Economic Studies. Vol. 10, No. 1, September.

29. Rahman, A.R. (1996), «Administrative responsibility: an Islamic perspective», American Journal of Islamic Social Sciences, Vol. 3 No. 4, pp. 497-517.

30. Rizk, R. R. (2008). «Back to basics: an Islamic perspective on business and work ethics», Social Responsibility Journal, 4(2): 246-254.

31. Saunders, M (2009) Research Method for Business Students ( $5^{\text {th }}$ edn.) England: Pearson Education Limited.

32. Schuler, Randall S., and Jackson, Susan E. (2007) Strategic Human Resource Management. Australia: Blackwell Publishing Ltd.

33. Shamsudin, A. S. B., Kassim, A. W. B. M., Hassan, M. G., Johari, N. A. (2010) «Preliminary Insights on the Effect of Islamic Work Ethic on Relationship Marketing and Customer Satisfaction». The Journal of Human Resource and Adult Learning. Vol.6, No.1, June.

34. Siddiqi. M, 2002, Comparative Advantages of Islamic Banking and Finance, viewed 24/01/2005, http://www.siddiqi.com/mns/Advantages.html. Access on $15^{\text {th }}$ of July 2016

35. Tijjani, Ahmad (2011) http://www.sunnewsonline.com/webpages/opinion/2011/july/ 12/opinion-12-07-2011-002.html. Access on $14^{\text {th }}$ of July 2015 at 21.08

36. Turban, et al. (2002). Electronic Commerce: A Managerial Perspective. New Jersey: Prentice Hall.

37. Yin, Robert. K. (2009) Case Study Research: Design and Methods. London: Sage.

38. Yusri, A. 2005, Islamonline.net, http://www.Islamonline.net/Arabic/contemporary/2005/06/ article04.shtml. Access on $12^{\text {th }}$ of July 2016

39. Zaher, T.S. and Hassan, M.K. (2001) A Comparative Literature Survey of Islamic Finance and Banking, Financial Markets, Institutions \& Instruments 10 (4), 155-199

40. Zarqa, M. (2003). Islamization of Economics: The Concept and Methodology. Journal of KAU: Islamic Economies. vol.16, no.1, pp.3 -42.

41. Zeithaml, V.A., Mary, J.B., and Grembler, D.D. (2009). Service Marketing: Integration Customer Focus across the Firm. New York: McGraw-Hill. 